\title{
MENELITI AGAMA DENGAN PENDEKATAN CULTURAL STUDIES
}

\author{
Rahmadi
}

\author{
Universitas Islam Negeri Antasari
}

rahmadi.uin.antasari@gmail.com

Diterima 15 Februari 2018 | Direview 27 Agustus 2018| Diterbitkan 01 Desember 2018

\begin{abstract}
:
This article provides a description of the use of cultural studies approaches in religious research. Here it is stated in general about the definition, purpose, characteristics and methods of cultural studies. Religious research can utilize several cultural studies methods, including ethnography, semiotics, discourse analysis, genealogy, deconstruction, case studies, grounded theory and others. In the study of scriptures can also be applied several cultural studies readings such as (1) reading structuralism, (2) reading postrukturisme, (3) reading semiotics, (4) reading fetishism, and (5) deconstructive reading. The use of cultural studies in religious research can cause problems and even rejection if the results harm religion. To avoid the negative or harmful effects that might result from religious studies, this approach needs to be carefully controlled and used to minimize the damaging effects and utilize its dynamic, productivity and reconstructive effects to enrich religious studies.
\end{abstract}

Keywords: Research, Religion, Cultural Studies Approach.

\begin{abstract}
Abstrak:
Artikel ini memberikan deskripsi mengenai penggunaan pendekatan cultural studies dalam penelitian agama. Di sini dikemukakan secara umum mengenai definisi, tujuan, karakteristik dan metode cultural studies. Penelitian agama dapat memanfaatkan beberapa metode cultural studies, di antaranya etnografi, semiotika, analisis wacana, genealogi, dekonstruksi, studi kasus, grounded theory dan lainnya. Dalam studi kitab suci dapat juga diterapkan beberapa pembacaan cultural studies seperti (1) pembacaan strukturalisme, (2) pembacaan postrukturalisme, (3) pembacaan semiotika, (4) pembacaan fetisisme, dan (5) pembacaan dekonstruktif. Penggunaan cultural studies dalam penelitian agama dapat menimbulkan problem bahkan penolakan jika hasilnya merugikan agama. Untuk menghindari efek negatif atau mudarat yang mungkin ditimbulkannya dalam studi agama, pendekatan ini perlu dikendalikan dan digunakan secara hati-hati untuk meminimalisir efek merusaknya dan memanfaatkan efek-efek dinamis, produktivitas dan rekonstruktifnya untuk memperkaya telaah agama.
\end{abstract}

Kata Kunci: Penelitian, Agama, Pendekatan, Cultural Studies.

\section{Pendahuluan}

Pencarian model dan metode penelitian yang tepat terhadap agama telah lama didiskusikan kalangan intelektual atau para akademisi perguruan tinggi di Indonesia. Sejak awal tahun 60-an, pencarian itu mulai intensif dilakukan melalui berbagai pertemuan ilmiah untuk menemukan format penelitian agama yang tepat. Pencarian ini disebabkan munculnya berbagai metode yang bervariasi dalam berbagai disiplin ilmu, baik dalam bidang sains, ilmu sosial dan humanitas. Pertanyaan yang muncul adalah apakah metode ilmiah, metode ilmu sosial dan humanitas itu dapat dan tepat untuk diaplikasikan dalam meneliti agama ataukah meneliti agama harus menggunakan metode khusus atau pendekatan tersendiri. Hasil riset Rahmadi, dkk terkait pencarian ini menemukan beberapa usulan dari kalangan intelektual di Indonesia, yaitu (1) usulan agar penelitian agama menggunakan metodologi atau pendekatan ilmiah yang sudah ada dan tidak perlu mencari metodologi khusus, (2) usulan agar menggunakan pendekatan ilmiah untuk meneliti gejala sosial-budaya dari kehidupan keagamaan sedang untuk aspek doktrinal sebaiknya menggunakan metode khusus, (3) usulan untuk menggunakan metode khusus secara keseluruhan dalam meneliti agama asal bentuk metodenya jelas, (4) usulan agar meneliti agama menggunakan metode sintesis (religioscientific), dan (5) usulan agar meneliti agama (Islam) tidak menggunakan pendekatan Barat karena dianggap berbahaya. ${ }^{1}$ 
Munculnya varian pemikiran semacam ini tidak terlepas dari adanya unsur sakralitas dalam agama sebagai objek studi di samping unsur profanitas yang menimbulkan pertanyaan bagaimana memperlakukan agama secara tepat dalam penelitian. Selain itu, fenomena keagamaan yang juga menjadi sasaran riset ilmu-ilmu sosial menimbulkan ketumpangtindihan bagi para peneliti juga menimbulkan pertanyaan bagaimana memahami dengan tepat, apakah melihatnya dari perspektif ilmu-ilmu sosial saja, perspektif agama secara normatif-doktrinal, atau keduanya?

Salah satu pendekatan baru yang juga menjadi perhatian peneliti agama adalah penggunaan pendekatan cultural studies untuk meneliti agama. Sebagai pendekatan yang belum banyak ditulis dalam literatur studi agama di Indonesia tentu menimbulkan sejumlah pertanyaan mengenai bentuk pendekatan ini. Di antaranya, apa yang dimaksud dengan cultural studies, bagaimana kemunculan dan perkembangannya, apa saja teori dan metodenya, bagaimana ia diaplikasikan dalam meneliti agama, dan model cultural studies yang seperti apa yang cocok untuk diaplikasikan dalam studi agama? Jawaban sejumlah pertanyaan ini akan dipaparkan pada tulisan ini meski tidak secara menjawab secara keseluruhan.

\section{Sekilas tentang Cultural Studies}

Menurut A.A. Ngr Anom Kumbara, sangat sulit untuk menentukan ataupun membatasi cultural studies sebagai suatu disiplin yang koheren, tunggal, dan akademis yang mampu membedakaannya dengan disiplin-disiplin lain. Secara definitif, ia mengartikan cultural studies sebagai studi kebudayaan atas praktik signifikasi representasi, dengan mengeksplorasi pembentukan makna pada beragam konteks. ${ }^{2}$ Akhyar Yusuf Lubis mengemukakan empat definisi cultural studies yang dikutipnya dari Barker, yaitu:

Pengertian pertama, Cultural Studies dapat dipahami sebagai kajian tentang hubungan (relasi) antara kebudayaan dan kekuasaan. Pengertian kedua, Cultural Studies dapat dipahami sebagai kajian tentang seluruh praktik institusi dan sistem klasifikasiyang tertanam dalam nilai-nilai partikular, kepercayaan, kompetensi, kebiasaanhidup, dan bentuk-bentuk perilaku yang biasa dari sebuah populasi. Pengertian ketiga, Cultural Studies dapat dipahami sebagai kajian tentang berbagai kaitan antara bentuk-bentuk kekuasaan gender, ras, kelas, kolonialisme dan sebagainya. Pengertian keempat, Cultural Studies dapat dipahami sebagai kajian mengenai berbagai kaitan wacana di luar dunia akademis dengan gerakan-gerakan sosial dan politik, para pekerja di lembagalembaga kebudayaan, manajemen kebudayaan dan lain sebagainya. ${ }^{3}$

Rachmah Ida mengemukakan definisi Cultural Studies dalam empat elemen sebagaimana yang dikemukakan oleh Baker. Pertama, Cultural Studies adalah kajian interdisipliner, dimana perspektif-perspektif dari disiplin ilmu yang berbeda dipakai untuk menjelaskan tentang budaya dan kekuasaan. Kedua, Cultural Studies memperhatikan semua praktik-praktik, insititusi-institusi (sosial, politik, budaya, ekonomi dsb), dan sistem-sistem klasifikasi yang terjadi dalam komunitas-komunitas. Ketiga, Cultural Studies mempertanyakan secara kritis bentuk-bentuk 'power' yang bervariasi dan berbeda meliputi: 'gender, ras, kelas, kolonialisassi, dsb.' Keempat, selain merupakan kajian akademik, Cultural Studies juga mencari hubungan di luar akademik dengan gerakan-gerakan atau perubahan-perubahan sosial dan politik, pekerja dalam institusi-institusi budaya dan manajemen budaya. ${ }^{4}$

${ }^{2}$ A.A. Ngr Anom Kumbara, "Genealogi Teori dan Metodologi di Cultural Studies", Jurnal Studi Kultural (2018) Volume III No.1, h. 38.

${ }^{3}$ Akhyar Yusuf Lubis, Pemikiran Kritis Kontemporer dari Teori Kritis Cultural Studies, Feminisme, Postkolonial bingga Multikulturalisme (Jakarta: PT RajaGrafindo Persada, 2015), h. 55-56.

${ }^{4}$ Rachmah Ida, Metode Penelitian Studi Media dan Kajian Budaya (Jakarta: Prenada Media Group, 2014), h. $2-3$. 
Karakteristik Cultural Studies menurut Akhyar Yusuf Lubis adalah: (1) Cultural Studies bertujuan meneliti kaitan kebudayaan dan praktik budaya dengan kekuasaan, yaitu menyingkap dimensi kekuasaan dan bagaimana ia memengaruhi bentuk kebudayaan; (2) Cultural Studies mengkaji budaya dalam konteks sosial-politik; (3) Cultural Studies mengkaji budaya dari aspek objek, lokasi tindakan dan selalu dalam tradisi kritis. Kajianya tidak hanya bertujuan merumuskan teori belaka tetapi juga merupakan suatu tindakan yang bersifat emansipatoris; (4) Cultural Studies berupaya mendekontruksi aturan dan pengkotak-kotakan ilmiah konvensional kemudian berupaya mendamaikan pengetahuan yang memilah antara objektif dan subjektif, antara universal dan partikular dan sebagainya; (5) Cultural Studies tidak bebas nilai dan melibatkan diri dengan nilai dan pertimbangan moral masyarakat serta tindakan politik dan konstruksi sosial. Ia bersifat ideologis-politis-emansipatoris karena memiliki tujuan mengubah struktur dominasi, struktur sosial-budaya yang menindas; (6) Cultural Studies bersifat lintas disipliner, ia sangat akrab dengan berbagai disiplin ilmu lain, yakni ia bebas meminjam dan mengambil "apa saja" teori dan metodologi disiplin ilmu lain yang dibutuhkan dan mengadopsinya untuk disesuaikan dengan tujuanya. ${ }^{5}$

Menurut Filiang, cultural studies belum merupakan sebuah disiplin keilmuan yang telah mapan, melainkan sebuah ide yang tengah berkembang dan tren pemikiran yang masih mencari bentuknya. Ada dua fase cultural studies, yaitu cultural studies modern dan cultural studise postmodern. ${ }^{6}$ Pada fase cultural studies modern isu sentralnya adalah tentang budaya populer, budaya massa, industrialisasi, kebudayaan dan industri, media massa, komodifikasi, struktur budaya, kode budaya, ideologi, subjek, hegemoni, struktur kelas, demokrasi dan kelas, resistensi, subversi, dan perlawanan. Arus pemikiran yang mempengaruhinya adalah kelompok pemikir kulturalis (Arnold, Richard,Leavis, Hoggart, William, Thompson), para pemikir sosiologis (Weber, Berger dan Luckman, Schutz), para pendukung Marxis Barat (Althusser, Adorno, Benjamin, Gramsci) dan para pemikir strukturalis (de Saussure, Barthes, Levi-Strauss). ${ }^{7}$

Pada fase Cultural studies postmodern, isu sentralnya adalah genesis, perubahan, produktivitas tanda, permainan bebas tanda, permainan bebas interpretasi, relativitas pengetahuan, mesin hasrat (desiring machine), ketidaksadaran (unconsciousness), ekonomi libido, heterogenitas, skizoprenia, nomadisme, smulasi, hiperrealitas, relasi pengetahuan dan kekuasaan (genealogi), teori wacana (discourse), pengetahuan lokal, etnisitas. Arus pemikiran yang mempengaruhinya adalah para pemikir poststrukturalis (Derrida, Barthes, Kristeva) dan postmodernis (Foucault, Deleuze, Guattari, Lyotard, dan Baudrillard). ${ }^{8}$

Dari perkembangan di atas, Filiang menyatakan bahwa cultural studies merupakan kecenderungan cara berpikir, model analisis, atau model pemahaman yang berkembang dengan mengombinasikan berbagai teori dan metode yang telah ada dan atau sedang berkembang sehingga sangat bersifat dinamis, terus bergerak, dan terus menjadi (becoming). Sebagai sebuah pendekatan, menurut Filiang, merekombinasikan secara eklektik dan bricolage berbagai pendekatan dan analisis yang telah ada, seperti teori budaya, kritik budaya, teori kritis, teori ideologi, teori subjek, antropologi, etnometodologi, semiotika, psikoanalisis, analisis teks, analisis wacana, dekonstruksi, skizoanalisis, dan genealogi. ${ }^{9}$

Konsep-konsep kunci cultural studies yang juga perlu dipahami sebagaimana dikemukakan oleh Rachmah Ida adalah (1) praktik-praktik budaya (signifying practices) dalam masyarakat yang menghasilkan makna, (2) representasi, (3) materialisme dan non-reductionisme,

\footnotetext{
${ }^{5}$ Akhyar Yusuf Lubis, Pemikiran Kritis Kontemporer, h. 56-57.

${ }^{6}$ Yasraf Amir Filiang, Bayang-bayang Tuhan; Agama dan Imajinasi (Mizan: Bandung, 2011), h. 137-138.

${ }^{7}$ Filiang, Agama dan Imajinasi, h. 138.

${ }^{8}$ Filiang, Agama dan Imajinasi, h. 138.

${ }^{9}$ Filiang, Agama dan Imajinasi, h. 138.
} 
(4) artikulasi, (5) kekuasaan (power), (6) budaya populer, (7) teks dan pembaca/penonton, dan (8) subjetivitas dan identitas. ${ }^{10}$

Menurut Akhyar Yusuf Lubis metode penelitian yang digunakan dalam studi cultural studies pada dasarnya menggunakan metode interpretatif (hermeneutik/partisipatoris) dan konstruktivis karena budaya dilihat sebagai "teks". Di sini teks tidak hanya terbatas tulisan dengan berbagai bentuknya tetapi juga mengacu pada segala sesuatu yang menghasilkan makna melalui praktik pemaknaan. Di sini film, iklan, budaya konsumerisme, tayangan televisi, dunia fashion, media, budaya publik, budaya cyber, budaya ilmiah, budaya multikultural, dan sebagainya termasuk pada makna "teks" dalam perspektif studi cultural studies. Di antara metode yang digunakan untuk meneliti budaya sebagai "teks" adalah metode etnografi dan metode semiotika. ${ }^{11}$ Di sini terlihat apa yang disebut teks yang menjadi objek interpretasi dalam cultural studies tidaklah bermakna sempit. Teks dalam konteks cultural studies sebagaimana yang ditulis oleh Rachmah Ida adalah mencakup semua yang tertulis, gambar, film, video. foto, desain grafis, lirik lagu dan lain-lain yang menghasilkan makna. Di sini teks tidak hanya terbatas pada apa yang diproduksi oleh media massa, tetapi juga realitas sehari-hari yang mempunyai makna. ${ }^{12}$

Metode etnografi yang lahir dari studi Antropologi dalam cultural studies digunakan untuk memahami dan menafsirkan suatu budaya atau sistem kelompok tertentu dengan menekankan studi mendalam terhadap ihwal perilaku dengan menggunakan sudut pandang budaya atau kelompok sosial itu sendiri. Peneliti yang menggunakan metode ini harus berinteraksi, menjalin hubungan dan bergaul langsung dengan kelompok sosial yang diteliti. Sementara metode semiotika dalam cultural studies digunakan untuk memahami sistem tanda yang terdapat pada budaya fashion, budaya populer, iklan dan sebagainya. Pada metode ini realitas (sosial, budaya, politik dan sebagainya) dianggap sebagai kontruksi atau representasi yang tidak terlepas dari tanda: tanda, simbol, ideologi, kepentingan atau kuasa tertentu. $^{13}$

Selain kedua metode di atas, menurut Akhyar Lubis, ada lagi beberapa metode atau teori yang sering digunakan dalam studi culturual studies. Pertama, Genealogi, yakni bentuk penelusuran historis tentang bagaimana terbentuknya (terkonstruksinya) berbagai macam pengetahuan (episteme), objek-objek pengetahuan dan wacana ilmiah. Metode ini digunakan untuk studi cultural studies terhadap ilmu pengetahuan. Kedua, dekonstruksi, yakni pembongkaran argumentatif untuk memunculkan lapisan-lapisan makna dalam teks sehingga makna-makna yang selama ini tidak muncul dalam teks karena dipinggirkan, ditekan, diabaikan dan lain sebagainya dapat muncul. Teori dekontruksi pada cultural studies amat berguna untuk menyingkap lapisan-lapisan makna yang selama ini terpendam dalam teks. Ketiga, analisis wacana, yaitu kajian yang berupaya menyingkap dimensi-dimensi kepentingan dan kekuasaan yang terselubung atau tersembunyi dalam praktik bahasa (media). Dalam cultural studies analaisis wacana digunakan dalam mengkaji praktik media. Keempat, teori feminisme dengan menggunakan pendekatan analisis gender, yaitu kajian yang berupaya membongkar mulai dari kontruksi bahasa hingga konstruksi sosial yang menstereotipkan perempuan. Pada studi cultural studies teori ini berguna untuk memahami bagaimana citra perempuan dikontruksi seperti lewat media. Kelima, teori postkolonial, yaitu teori yang menyuguhkan kritik terhadap praktik dan dampak praktik kolonialisme terhadap bangsa jajahan (seperti sikap inferior, identitas ganda, budaya hibdrid pada bangsa jajahan). Teori ini pada cultural studies berguna dalam memahami terjadinya percampuran budaya, persoalan identitas dan sebagainya. Keenam, teori neo-Marxisme yang digunakan memahami

\footnotetext{
${ }^{10}$ Penjelasan singkat mengenai konsep-konsep ini dapat dibaca pada: Rachmah Ida, Metode Penelitian Studi Media dan Kajian Budaya, h. 4-9.

${ }^{11}$ Akhyar Yusuf Lubis, Pemikiran Kritis Kontemporer, h. 74-75.

${ }^{12}$ Rachmah Ida, Metode Penelitian Studi Media dan Kajian Budaya, h. 62.

${ }^{13}$ Akhyar Yusuf Lubis, Pemikiran Kritis Kontemporer, h. 75-76.
} 
persoalan-persoalan seperti kesadaran palsu, fetisisme komoditi, rezim wacana, relasi kelas yang dibangun atas dasar dominasi dan hegemoni, massifikasi produk-produk industri dan sebagainya. Dalam studi cultural studies teori ini digunakan untuk memahami bagaimana kepentingan-kepentingan kelompok dominan bekerja dalam kehidupan sosial-budaya. Ketujuh, penelitian aksi partisipatoris, jenis penelitian ini dalam cultural studies digunakan untuk memahami relasi kekuasaan yang terdapat dalam kehidupan sosial-politik-budaya di tengah masyarakat sekaligus menyuarakan suara masyarakat yang selama ini dibungkam dan merumuskan langkah-langkah strategis guna mengemansipasi masyarakat. Kedelapan, studi kasus, yaitu salah satu varian studi kualitatif yang digunakan dalam studi cultural studies untuk meneliti secara detail, khusus, dan mendalam terhadap objek yang diteliti untuk memperoleh pemahaman yang jelas dan konprehensif. Kesembilan, penelitian naratif, yaitu laporan naratif yang menceritakan urutan peristiwa secara detail atau terperinci. Dalam cultural studies penelitian jenis ini digunakan untuk memahami praktik-prakti budaya berdasarkan sudut pandang partisipan sendiri; bukan dari perspektif kelompok dominan yang selama ini mengonstruksi mereka. Kesepuluh, teori kekerasan simbolik, dalam cultural studies digunakan untuk memahami mekanisme kekerasan dalam bentuk lain (nonfisik, halus, dan tak terlihat) yang bekerja di tengah kehidupan masyarakat (sosial, media, pendidikan, politik, budaya dan seterusnya). Kesebelas, teori hiperrealitas, yaitu teori yang menjelaskan bagaimana permainan tanda-tanda berlangsung, bagaimana antara yang real dengan yang semu berbaur dan melebur hingga sulit dibedakan, dan bagaimana dunia tiruan terbentuk dan sebagainya. Teori ini berguna terutama untuk melihat dan memahami budaya virtual atau budaya cyber, komunikasi massa atau media, fashion, budaya konsumerisme dan ssebagainya. Keduabelas, studi teorisasi dasar (grounded theory), yaitu studi kualitatif untuk menemukan sisi-sisi atau dimensi-dimensi baru yang berasal dari proses sosial dari berbagai fenomena kehidupan manusia. Metode ini menggunakan perspektif interaksi simboli, yaitu mempelajari interaksi antarmanusia dan berusaha memahami perilaku dan bahasa mereka dengan memberikan makna dan simbol-simbol kehidupan tertentu untuk pemikiran dan tindakan mereka sendiri. Dalam cultural studies metode ini digunakan untuk memahami bagaimana individu-individu saling melakukan pemaknaan. ${ }^{14}$

Menurut Rachmah Ida metodologi dalam cultural studies yang banyak dipraktikan ada tiga. Pertama, etnografi yang banyak digunakan dalam antropologi. Kedua, pendekatanpendekatan tekstual (semiotik, post-strukturalisme, narrative theory dan dekontruksi Derridean). Ketiga, reception studies (studi-studi penerimaan) yang dianggap kaya akar teorinya. ${ }^{15}$ Menurut Filiang, ada beberapa metode cultural studies. Pertama, metode etnografi, yaitu salah satu metode klasik di dalam cultural studies yang dikembangkan ke arah yang lebih kualitatif. Etnografi bertujuan memahami makna, sebagaimana dipahami oleh sebuah komunitas atau masyarakat. Kedua, metode semiotika. Metode semiotika merupakan metode utama di dalam cultural studies sebagaimana juga di dalam postmodernisme. Semiotika adalah adalah ilmu yang menelaah tentang tanda sebagai sebagai bagian dari kehidupan sosial. Ketiga, metode dekontruksi, yaitu model analisis, cara berpikir dan metode yang berkaitan dengan pembongkaran terhadap berbagai struktur (bahasa, kekuasaan, institusi, objek sosial) yang ada, dalam rangka mengatasi berbagai bentuk ketidaksetaraan dan ketidakadilan yang ada di dalamnya. Keempat, metode genealogi. Genealogi berupaya untuk menyingkap relasi yang melekat antara praktik sosial, pengetahuan yang melandasinya (knowledge), dan relasi kekuasaan (power relation) yang beroperasi di dalamnya, yang membentuk berbagai wacana atau discourse (wacana politik, hukum, pendidikan, media, dan seni). Ada hubungan timbal balik antara pengetahuan dan kekuasaan. Pengetahuan menciptakan kekuasaan, dan sebaliknya kekuasaan dapat

\footnotetext{
${ }^{14}$ Akhyar Yusuf Lubis, Pemikiran Kritis Kontemporer, h.78-81.

${ }^{15}$ Rachmah Ida, Metode Penelitian Studi Media dan Kajian Budaya, h. 10-11.
} 
memproduksi pengetahuan. Genealogi dapat dilihat sebagai metode dalam membongkar berbagai struktur kekuasaan tak tampak di dalam berbagai discourse. ${ }^{16}$

\section{Aplikasi Pendekatan Cultural Studies dalam Studi Agama}

Menurut Filiang, telaah agama dengan menggunakan pendekatan cultural studies merupakan tantangan tersendiri. Masalah pertama yang menjadi tantangannya adalah telaah agama telah memiliki model telaah yang mencukupi bagi dirinya sendiri dan dikaji berdasarkan model epistemologi yang inheren di dalam sistem agama itu sendiri. Agama selalu dikaji melalui pendekatan ilmu agama itu sendiri. Telaah agama dari sudut pandang disiplin keilmuan lain masih dianggap asing, kalau tidak dikatakan mengancam otoritas keilmuan agama. Salah satu isu yang sangat fundamental sekaligus sensitif dalam telaah agama adalah tentang tafsiran atau interpretasi. Institusi agama dianggap satu-satunya otoritas dalam menafsirkan ayat-ayat suci, karena dalam penafsiran diperlukan semacam kompetensi yang hanya dimiliki oleh pakar-pakar tertentu yang telah terlatih di dalam metode dan prosedur-prosedur pembacaan yang bersifat internal dalam wacana keagamaan itu sendiri. ${ }^{17}$

Masalah kedua yang menjadi tantangannya menurut Filiang adalah keengganan untuk melihat agama dari luar medan wacana keagamaan itu sendiri, menjadikan agama sangat resisten terhadap kritik diri, hal yang justru sangat diperlukan dalam meningkatkan produktivitas dan dinamika pengetahuan (keagamaan). Tentu saja, tulis Filiang, para otoritas pengetahuan keagamaan enggan untuk melakukan proses penelanjangan diri sendiri atau disebut juga oleh Foucault sebagai genealogi karena semuanya akan berujung pada otoritas institusi agama bahkan Tuhan itu sendiri. Para otoritas agama, tentu tidak akan sudi menggunakan pendekatan dekontruksi Derrida dalam telaah agama lantaran dapat menjadikan kebenaran agama menjadi samar-samar dan tanpa ada kepastian. ${ }^{18}$

Meskipun ada tantangan yang demikian, menurut Filiang, penggunaan cultural studies tidak bisa diabaikan dan penting digunakan. Cultural studies menurut Filiang akan membantu studi agama dalam melakukan interpretasi yang berorientasi ke masa depan (prospektive interpretation) agar agama mampu menghadapi perubahan zaman dan tidak termarjinalkan atau hanya dijadikan sebagai sekadar objek perubahan. Dalam pandangan cultural studies, selama ini interpretasi agama terlalu berorientasi ke belakang, yakni mencari kebenaran yang telah dirumuskan di masa lalu (logos) dengan bertumpu pada model interpretasi retrospek.tif. ${ }^{19}$

Untuk menghindari efek kelemahan, bahaya, ancaman, atau mudarat yang ditimbulkan dalam studi dan kehidupan agama, pendekatan cultural studies perlu dijinakkan untuk meminimalisir efek merusaknya dan memanfaatkan efek-efek dinamis, produktivitas dan rekonstruktifnya untuk memperkaya telaah agama. Telaah agama, menurut Filiang, dapat mengambil keuntungan dari pendekatan hermeneutika, semiotika, strukturalisme, dan poststrukturalisme. ${ }^{20}$

Pemanfaatan pendekatan cultural studies dengan segala implikasinya dalam studi agama sebagaimana disebutkan Filliang di atas dapat dilihat dari penggunaan pendekatan postmodernisme dalam studi agama sebagaimana yang ditulis oleh Rudy Harisyah Alam yang berjudul "Perspektif Pasca-Modernisme dalam Kajian Keagamaan". Gagasan penting Alam dalam tulisannya ini adalah penggunaan perspektif, analisis, atau strategi postrukturalisme untuk mengkaji agama dalam perspektif Michel Foucault dan Jacques Derrida. Penggunaan kedua perspektif tokoh ini tidak dimaksudkan sebagai bentuk

\footnotetext{
${ }^{16}$ Filiang, Agama dan Imajinasi, h. 149-153.

${ }^{17}$ Filiang, Agama dan Imajinasi, h. 153-154.

${ }^{18}$ Filiang, Agama dan Imajinasi, h. 155.

${ }^{19}$ Filiang, Agama dan Imajinasi, h. 154-155.

${ }^{20}$ Filiang, Agama dan Imajinasi, h. 155.
} 
rekonsiliasi tetapi dalam bentuk komplementer untuk menghasilkan bentuk studi agama yang kritis. ${ }^{21}$

Perspektif Foucault yang ditawarkan oleh Rudy Harisyah Alam adalah tentang diskursus (wacana), analisis arkeologis, analisis genealogi dan relasi-relasi kuasa. Diskursus (discource) atau wacana yang ditetapkan oleh suatu komunitas yang berwenang dianalisis melalui analisis arkeologis. Di sini wacana diperlakukan sebagai praktik-praktik yang secara sistematis membentuk objek-objek yang dibicarakan. Fokus utamanya adalah bagaimana wacana membentuk objek-objek pembicaraan dan bagaimana wacana itu terbentuk. Analisis arkeologis digunakan untuk melakukan reduksi ganda guna menyingkap wilayah "pembentukan wacana" (discursive formation). Reduksi pertama, menunda seluruh pertanyaan yang berhubungan dengan persoalan referensi dan klaim validitas (benar-salah) hingga hanya menyisakan makna sebuah wacana. Reduksi kedua, menunda juga "makna" untuk mengenyampingkan subjektivitas. ${ }^{22}$

Menurut Alam, Foucault mengembangkan analisis genealogis untuk melengkapi analisis arkeologisnya, yaitu kajian yang berusaha mendeskripsikan sejarah formasi-formasi sosial dari praktik-praktik non-diskursif. Fokus sentralnya adalah "relasi-relasi kekuasaan" yang imanen dalam formasi-formasi sosial. Kuasa dalam perspektif Foucault merupakan suatu bentuk hubungan yang secara imanen terwujud dalam relasi-relasi lainnya, seperti relasi politik, ekonomi, seksual, keluarga dan agama. Kuasa tidak hanya bersifat destruktif dan represif (membatasi, mengontrol, memberi sanksi, mengucilkan, dan menundukkan) tetapi ia juga bersifat positif, konstruktif, dan emansipatif, artinya ia juga menawarkan kesenangan, membentuk pengetahuan dan memproduksi berbagai wacana. Perpaduan analisis arkeologis dan genealogis ini akan membentuk kritisme baru. Kritisme ini bersifat genealogis dalam desainnya dan bersifat arkeologis dalam metodenya. Kritisme baru ini jika diaplikasikan dalam wilayah kajian agama diharapkan dapat melahirkan sebuah perspektif studi agama yang kritis. $^{23}$

Penekanan penggunaan analisis genealogis-arkeologis dalam studi agama, menurut Alam, diarahkan pada aspek eksterioritasnya, yakni mengkaji agama dalam kaitannya dengan relasi-relasi kekuasaan yang imanen yang terdapat dalam wacana dan praktik keagamaan, bukan di balik, di belakang, ataupun sebagai sesuatu yang melampauinya. Kajian terhadap agama lebih diarahkan pada pembentukan wacana keagamaan, yaitu bagaimana peran faktorfaktor seperti ekonomi, politik, keluarga, dan lain sebagainya dalam proses pembentukan wacana keagamaan. Ia melakukan jukstaposisi (penjajaran) atas bermacam wacana keagamaan yang berbeda, menjelaskan perbedaannya, memperlihatkan hubungannya satu sama lain, dan mencermati bagaimana sebuah wacana keagamaan dapat mendominasi, mengeksklusi, membatasi, menundukkan, menguatkan, dan mengintegrasi - diskursus keagamaan lainnya. ${ }^{24}$

Untuk mengaplikasikan analisis genealogis-arkeologis dalam perspektif Foucaultian dalam studi agama secara sistematis, Alam menawarkan langkah-langkah berikut. Pertama, menginventarisasi praktik-praktik sosial (nondiskursif) yang akan menjadi sasaran investigasi, yaitu praktik-praktik yang secara efektif yang menjadi wilayah di mana relasi-relasi kekuasaan menghasilkan efeknya yang represif. Kedua, mendeskripsikan bagaimana relasi-relasi kekuasaan bekerja lewat mekanisme yang disediakan oleh praktik-praktis sosial tersebut dan bagaimana relasi-relasi kuasa tersebut dapat memproduksi dan memunculkan wacana

${ }^{21}$ Rudy Harisyah Alam "Perspektif Pasca-Modernisme dalam Kajian Keagamaan" dalam M. Deden Ridwan (ed.), Tradisi Penelitian Agama Islam Tinjauan Antardisiplin Ilmu, (Bandung: Nuansa, 2001), h. 93-94.

22Alam "Perspektif Pasca-Modernisme", h. 94-95; Rahmadi, dkk., Dinamika Pemikiran Sarjana Muslim, h. 161. 162.

${ }^{23}$ Alam "Perspektif Pasca-Modernisme", h. 96; Rahmadi, dkk., Dinamika Pemikiran Sarjana Muslim, h. h. $162-163$ 
keagamaan. Ketiga, menganalisis bagaimana berbagai wacana keagamaan yang telah diproduksi oleh relasi-relasi kuasa itu kemudian menopang dan menjustifikasi bekerjanya relasi-relasi kuasa tersebut dalam memproduksi suatu kebenaran, pengetahuan dan strategi diskursif yang dimanfaatkan untuk memelihara keberlangsungan relasi-relasi kuasa. Keempat, menjukstaposisi berbagai diskursus keagamaan yang berbeda, memperlihatkan hubungan satu sama lain, dalam satu efek yang saling menguatkan, saling membatasi, saling mengeksklusi, saling mengintegrasikan dan sebagainya. ${ }^{25}$

Penggunaan analisis genealogis-arkeologis dalam studi agama tidaklah cukup. Hal ini disebabkan perspektif Foucaultian tidak menyediakan suatu cara tertentu bagaimana membangkitkan kembali wacana-wacana keagamaan yang telah ditundukkan oleh wacana keagamaan lain yang telah mendominasi. Karena itu, dalam perspektif Alam, diperlukan suatu cara untuk mengubah relasi-relasi kuasa yang ada agar tidak menghasilkan efek yang represif. Untuk cara ini, Alam mengusulkan untuk menggunakan strategi dekontruksi yang telah dikembangkan oleh Jacques Derrida ${ }^{26}$.

Dekontruksi (pembongkaran), menurut Alam, merupakan sebuah strategi untuk memperlihatkan ambiguitas sebuah wacana dengan jalan menelusuri gerakan-gerakan paradoksal yang terdapat di dalam wacana itu sehingga setiap unit wacana mensubversi dasar-dasar asumsi yang dimilikinya sendiri. Dengan menggunakan strategi dekonstruksi, maka wacana keagamaan yang ditundukkan akan membentuk struktur resistensi bersama terhadap wacana yang dominan. Dengan meruntuhkan struktur hirarkis yang membentuk suatu hubungan dominasi-subordinasi, wacana-wacana keagamaan yang ditundukkan dapat meruntuhkan peran legitimasi dan justifikasi relasi-relasi kuasa refresif yang ditopang oleh wacana keagamaan yang dominan itu. Relasi-relasi kuasa yang refresif itu akan dapat ditransformasikan menjadi relasi-relasi kuasa dalam bentuknya yang positif. ${ }^{27}$

Penggunaan analisis arkeologis-genealogis dan strategi dekontruksi secara komplementer dalam studi agama, menurut Alam, dapat membentuk sebuah perspektif studi agama yang kritis untuk melibatkan diri pada investigasi historis atas praktik-praktik keagamaan yang bersifat diskursif maupun sosial, guna menyingkap suatu wilayah bekerjanya relasi-relasi kuasa. Penggunaan analisis komplementer ini juga dapat membentuk studi agama yang praktis, yaitu menyediakan suatu "ontologi historis" diri kita sendiri dalam suatu wilayah relasi-relasi kuasa, terutama untuk terlibat dalam "perjuangan" mentransformasikan bentuk-bentuk represif dari relasi-relasi kuasa kepada bentuknya yang positif. ${ }^{28}$

Jika Rudy Harisyah Alam menawarkan perspektif postmodernisme yang juga menjadi bagian metodologis dari cultural studies untuk menghasilkan sstudi agama yang kritis terutama dalam membongkar unsur kuasa dalam wacana keagamaan, maka Filiang juga memberikan contoh bagaimana pendekatan cultural studies digunakan dalam pembacaan (pemahaman dan penafsiran) terhadap kitab suci agama yang dilakukan oleh masyarakat atau penganut agama. Di sini Filiang menawarkan ragam pembacaan teks suci. Ia memperlihatkan bagaimana cultural studies dipergunakan dalam studi agama, yaitu pembacaan cultural studies dalam studi Alquran, yaitu memahami bagaimana pembacaan masyarakat terhadap Alquran. Di sini ia menawarkan beberapa pembacaan, yaitu (1) pembacaan strukturalisme, (2) pembacaan postrukturalisme, (3) pembacaan semiotika, (4) pembacaan fetisisme, dan (5) pembacaan dekonstruktif.

Pembacaan strukturalisme relevan dalam menelaah pembacaan masyarakat terkait struktur Alquran. Melalui model ini relasi-relasi di antara elemen-elemen tanda dan bahasa,

${ }^{25}$ Alam ,"Perspektif Pasca-Modernisme", h. 100; Rahmadi, dkk., Dinamika Pemikiran Sarjana Muslim, h. 163.

26Rahmadi, dkk., Dinamika Pemikiran Sarjana Muslim, h. 163.

${ }^{27}$ Alam ,"Perspektif Pasca-Modernisme", h. 102-103; Rahmadi, dkk., Dinamika Pemikiran Sarjana Muslim, h. 163-164.

${ }^{28}$ Rahmadi, dkk., Dinamika Pemikiran Sarjana Muslim, h. 164. 
serta kode atau konvensi yang mengatur relasi tersebut dalam struktur bahasa Alquran dapat dipelajari. Pada telaah ini, pembacaan strukturalisme terfokus pada apa yang telah disepakati secara konvensional dalam ajaran agama itu sendiri, tafsir teks mengarah ke masa lalu. Tugas penafsir adalah menemukan struktur dan kode-kode yang telah ada tersebut. ${ }^{29}$

Pembacaan postrukturalisme memberi ruang bagi penafsir untuk melakukan pembacaan bebas terhadap teks Alquran karena pendekatan ini memberi ruang permainan bebas, kreativitas, dan produktivitas penafsiran. Dalam arti, pembaca sebuah teks (Alquran) dapat lebih terbuka terhadap berbagai kemungkinan penafsiran dan dapat melepaskan diri dari konteks awal teks (Alquran). Pembacaan seperti ini mengandung risiko epistemologis, yakni teks dibaca secara terbuka tanpa melihat konteks awal pesan teks sehingga bisa terputus sama sekali dari makna awalnya. Pembacaan seperti ini dapat menjelma tafsiran murni imanensi yang dalam hal tertentu bersifat anarkistik dan antiteologis. ${ }^{30}$

Pembacaan semiotika memiliki dua pendekatan, yaitu pendekatan semiotika struktural (structural semiotics) yang lebih menekankan telaah tanda sebagai sebuah sistem, struktur dan relasi (langue), dan pendekatan semiotika sosial (social semiotics) yang memusatkan perhatian pada penggunaan tanda secara konkret di dalam masyarakat (parole). Dalam kajian semiotika terdapat beberapa pembacaan yang dapat diterapkan pada teks Alquran. Pertama, pembacaan denotatif (denotative reading) melalui pembacaan harfiah, yakni pembacaan teks (Alquran) pada tingkat permukaan tanda, tanpa menyelami kedalamannya, sehingga menghasilkan makna-makna yang langsung dan eksplisit. Kedua, pembacaan konotatif (connotative reading), yaitu pembacaan teks (Alquran) secara kontekstual, yakni pembacaan pada tingkat makna dalam, dengan mengaitkan apa yang secara harfiah tersurat dalam di dalam teks dengan berbagai bentuk emosi, perasaan, sentimen, perhatian, kepentingan, hasrat, dan kepercayaan yang ada pada tingkat individu maupun sosial dalam rangka menemukan makna implisit atau makna lapis kedua pada teks. Ketiga, pembacaan dekontekstual (decontextual reading), yaitu pembacaan teks (Alquran) secara konotatif tetapi tidak kontekstual, yakni mengaitkan sebuah teks atau bagian teks tersebut dengan maknamakna implisit di luar konteks awal sebuah teks. Penafsiran terlepas dari objek dan konteks atas teks itu sendiri sehingga ia menemukan makna dalam konteks yang baru sama sekali. Keempat, pembacaan fetistik (fetishtic reading), yaitu pembacaan msitifikasi yang melepaskan sebuah teks dari konteks komunikatifnya dengan cara menetralkan pesan-pesan komunikatif yang dibawanya (textual message), kemudian mengisi teks tersebut dengan sebuah kekuatan mistik atau daya pesona tertentu yang dapat mempengaruhi orang yang menggunakannya. Kelima, pembacaan dekonstruksi (deconstructive reading), yaitu pembacaan yang melepaskan teks (Alquran) dari konteks komunikatifnya dengan cara menetralkan pesan-pesan komunikatif yang dibawanya (textual message) untuk menjadikannya sebagai sebuah penanda baru tanpa henti dan dengan konteks yang baru dalam rangka menghasilkan perbedaan dan permainan kultural semata (free play of sign). ${ }^{31}$

Pembacaan fetisisme. Menurut Filiang, pembacaan fetisisme adalah satu bentuk designifikasi yang melaluinya sebuah tanda (teks) ditanggalkan rantai dan relasi pertandaannya, kemudian dimuati dengan relasi-relasi lain, khususnya kekuatan, pesona, atau mistifikasi tertentu. Dalam pembacaan fetisisme, Alquran dijadikan sebagai objek pemujaan karena di dalamnya dianggap bersemayam kekuatan-kekuatan tertentu sementara kandungan isi dan pesan ruhaniahnya dikosongkan kemudian diisi dengan dengan sebuah kekuatan mistik tersendiri yang dapat menyembuhkan, meramal dan sebagainya. Misalnya, miniatur Alquran (dicetak dengan ukuran yang sangat kecil) dibungkus dengan kain hitam yang diisi

\footnotetext{
${ }^{29}$ Filiang, Agama dan Imajinasi, h. 120-121.

${ }^{30}$ Filiang, Agama dan Imajinasi, h. 122-123.

${ }^{31}$ Filiang, Agama dan Imajinasi, h. 127-128.
} 
dengan berbagai ramuan rempah-rempah dan dipasang dipinggang sebagai benda untuk penolak balaatau penangkal ilmu-ilmu hitam lainnya. ${ }^{32}$

Pembacaan dekonstruksi. Dekonstruksi dibangun atas prinisp oversignifikasi. ${ }^{33}$ Ia melepaskan diri dari dari konteks atau kode awal sebuah teks dan menafsirkan teks tersebut di dalam sebuah proses intepretasi yang tanpa akhir dan tanpa makna akhir (interpretation of interpretation). Dalam pembacaan terhadap teks suci, ia memungkinkan dan mendorong munculnya tafsiran prospektif, yaitu tafsiran yang bersifat terbuka dan secara eksplisit menerima berbagai bentuk ketidakpastian, kontradiksi, dan paradoks yang ditimbulkan oleh bahasa. Ia tidak lagi terbatas pada rekontruksi makna awal (original) tetapi melihat ke depan guna menemukan berbagai kreativitas dan produktivitas tafsiran. Dengan melepaskan diri dari jangkar masa lalu itu maka terbukalah berbagai horizon baru yang sebelumnya dilarang atau tabu untuk dimasuki sehingga berbagai hal yang tidak terpikirkan dan tidak terbayangkan sebelumnya dapat disingkapkan. ${ }^{34}$

Selain beberapa metode di atas, studi agama dengan pendekatan cultural studies dapat mengaplikasikan metode interpretatif (hermeneutik) dan konstruktivis, karena pendekatan ini agama yang melekat pada budaya penganutnya diperlakukan sebagai "teks" yang dalam makna luas adalah segala sesuatu yang memiliki makna baik dalam bentuk tulisan maupun tidak (perilaku keagamaan). Metode etnografi dan semiotika dapat diaplikasikan di sini. Metode etnografi digunakan untuk memahami dan menafsirkan suatu fenomena keagamaan yang melekat pada budaya atau sistem kelompok tertentu dengan menekankan studi mendalam terhadap ihwal perilaku dengan menggunakan sudut pandang budaya atau kelompok sosial itu sendiri. Sementara metode semiotika digunakan untuk memahami sistem tanda yang terdapat pada budaya fashion, budaya populer, iklan dan sebagainya yang mengandung atau melibatkan unsur keagamaan.

Selain, etnografi dan semiotika, studi agama dengan menggunakan pendekatan cultural studies dapat pula mengaplikasikan beberapa metode berikut. Pertama, metode genealogi, yakni studi penelusuran secara historis tentang proses kontruksi aneka pengetahuan dan wacana ilmiah dalam wilayah keagamaan. Kedua, metode dekonstruksi, yakni pembongkaran diskursus keagamaan untuk memunculkan lapisan-lapisan makna yang selama ini terpendam dalam teks karena adanya peminggiran, tekanan, pengabaian dan lainnya. Ketiga, metode analisis wacana, yaitu studi yang berupaya menyingkap adanya relasi kuasa yang tersembunyi dalam wacana keagamaan yang dipresentasikan lewat media dan sebagainya. Keempat, metode analisis gender, yaitu kajian yang berupaya membongkar kontruksi bahasa agama dan konstruksi sosial penganut agama tertentu dalam mencitrakan perempuan. Kelima, metode aksi partisipatoris, yaitu kajian untuk memahami dan memberdayakan masyarakat penganut agama tertentu yang termarginalkan dalam hubungannya dengan kekuasaan tertentu. Keenam, metode studi kasus, yaitu kajian untuk meneliti secara detail, khusus, dan mendalam terhadap individu atau kelompok penganut agama untuk memperoleh pemahaman yang jelas dan konprehensif pada dimensi kehidupan keagamaan tertentu. Ketujuh, metode naratif (laporan yang menceritakan urutan peristiwa secara detail), yaitu kajian untuk memahami praktik-praktik budaya dalam konteks penganut agama tertentu berdasarkan sudut pandang partisipan sendiri; bukan dari perspektif kelompok dominan yang selama ini mengonstruksi mereka. Kedelapan, grounded theory, yaitu studi kualitatif untuk menemukan sisi-sisi atau dimensi-dimensi baru yang berasal dari proses sosial dari berbagai fenomena kehidupan keagamaan manusia. Metode ini digunakan untuk memahami bagaimana individu-individu penganut agama saling melakukan pemaknaan.

${ }^{32}$ Filiang, Agama dan Imajinasi, h. 129-131

${ }^{33}$ Oversignifikasi menempatkan penanda penanda di dalam rantai-rantai signifikasinya yang baru dengan cara terus-menerus atau tanpa akhir. Filiang, Agama dan Imajinasi, h. 131.

${ }^{34}$ Filinag, Agama dan Imajinasi, h. 131-133. 
Metode dan pendekatan cuktural studies dalam mengkaji agama tentu tidak hanya sebatas itu saja. Sesuai dengan wataknya, penggunaan pendekatan cultural studies dalam studi agama juga akan bersifat lintas disipliner dan dinamis, ia dapat mengadopsi metodologi disiplin ilmu lain yang dibutuhkan atau mengombinasikan berbagai metode yang sudah ada atau sedang berkembang dan diperlukan ketika melakukan kajian terhadap agama.

Untuk kepentingan kajian agama di perguruan tinggi Islam, Ahmad Muttaqin mengemukakan dua pilihan alternatif, menggunakan cultural studies model Inggris atau model Amerika. Model Inggris mengelaborasi teori-teori Kritis ala Marxis yang cenderung “dekonstruktif” dalam mengungkap ideologi di balik budaya, sementara model Amerika merupakan model cultural studies yang pragmatis dan cenderung "melegitimasi" budaya konsumtif-kapitalis atas nama kebebasan berekspresi. Menurutnya, model pertama lebih tepat dipergunakan di Perguruan Tinggi Islam dengan disertai catatan tebal. Budaya kontemprer yang berkembang di Perguruan Tinggi Islam berkaitan dengan tradisi keagamaan sehingga kajian cultural studies tidak diarahkan pada dekonstruksi praktik tradisi keagamaan tetapi untuk memunculkan kesadaran adanya hubungan antara pesan-pesan keagamaan dengan ideologi, kelas sosial maupun gender tertentu sehingga cara beragama seseorang tetap autentik dan tidak terjebak dengan kepentingan-kepentingan tertentu. ${ }^{35}$ Catatan semacam ini sejalan dengan peringatan Filliang di atas bahwa penggunaan cultural studies dalam kajian agama harus dijinakkan agar tidak menimbulkan efek merusak pada agama itu sendiri.

\section{Simpulan}

Cultural studies merupakan studi interdisipliner yang bersifat dinamis terhadap kebudayaan dan praktik budaya kaitannya dengan kekuasaan (power) yang berlangsung dalam berbagai institusi, komunitas, gerakan dan sebagainya dengan menggunakan kombinasi berbagai teori dan metode. Pendekatan ini belum mapan dan terus berkembang dan cenderung terus bergerak dan terus menjadi.

Pendekatan cultural studies dapat digunakan dalam kajian agama untuk memperkaya telaah agama dan membantu studi agama dalam melakukan interpretasi yang berorientasi ke masa depan (prospektive interpretation) serta melahirkan studi agama yang kritis. Meski demikian, penggunaan pendekatan ini mengandung problem, di antaranya adalah banyaknya varian teori dan metode yang dipakai dan bentuknya yang belum mapan membuatnya begitu terbuka bisa menimbulkan kesulitan bagi mereka yang belum terbiasa dengan pendekatan ini. Selain itu, beberapa metodenya yang dianggap rawan karena bisa menimbulkan efek merusak terhadap agama seperti timbulnya kesan kebenaran agama menjadi samar dan tidak memiliki kepastian. Karena itu, pengguna pendekatan ini dalam penelitian agama terlebih dahulu menjinakkan pendekatan ini jika ingin memanfaatkan teori dan metodenya yang begitu variatif.

\section{Daftar Pustaka}

Alam, Rudy Harisyah, (2001). "Perspektif Pasca-Modernisme dalam Kajian Keagamaan" dalam M. Deden Ridwan (ed.). Tradisi Penelitian Agama Islam Tinjauan Antardisiplin Ilmu, Bandung: Nuansa.

Amir Filiang, Yasraf, (2011). Bayang-bayang Tuban; Agama dan Imajinasi. Mizan: Bandung. Ida, Rachmah, (2014). Metode Penelitian Studi Media dan Kajian Budaya. Jakarta: Prenada Media Group.

Kumbara, A.A. Ngr Anom, (2018). "Genealogi Teori dan Metodologi di Cultural Studies". Jurnal Studi Kultural. Volume III No.1.

${ }^{35}$ Ahmad Muttaqin, "Geliat Cultural Studies Di PTAI, dalam Ahmad Muttaqin, dkk., Cultural Studies di PTAI Teori dan Praktek, (Yogyakarta: LABel, 2014), h. xvi-xvii. 
Muttaqin, Ahmad, (2014). "Geliat Cultural Studies Di PTAI”, dalam Ahmad Muttaqin, dkk., Cultural Studies di PTAI Teori dan Praktek. Yogyakarta: LABel,

Rahmadi, dkk, (2014). Dinamika Pemikiran Sarjana Muslim tentang Metodologi Studi Agama di Indonesia: Kajian terbadap Literatur Terpublikasi Tabun 1964-2012. Banjarmasin: IAIN Antasari Press.

Yusuf Lubis, Akhyar, (2015). Pemikiran Kritis Kontemporer dari Teori Kritis Cultural Studies, Feminisme, Postkolonial hingga Multikulturalisme. Jakarta: PT RajaGrafindo Persada. 

158 Ilmu Ushuluddin, hlm. 158-164

Desember 2018
Vol.17, No. 2, Juli- 